\title{
LEXICOGRAPHY AND NEW TESTAMENT CATEGORIES OF CHURCH DISCIPLINE
}

\author{
Andrew D. Clarke
}

\section{Summary}

A range of circumstances, which were formative in the crises prompting the Protestant Reformation, resulted in heightened emphasis on ecclesiastical discipline, with some Reformation Confessions elevating discipline 'according to the Word of God' to one of three significant 'marks' of the 'true church'. However, the Bible prompted no similar consensus among either the Reformers or the Reformation Confessions as to how, when, by or to whom such discipline should be exercised. Although the New Testament has no dominant vocabulary for 'discipline', the fixing on this term in the Sixteenth Century and subsequently nonetheless became a controlling principle in identifying and interpreting certain New Testament passages as 'disciplinary' in focus. Latin lexical roots pose an additional disjunction between firstcentury and post-Reformation legacy understandings of 'discipline'. Revisiting New Testament categories of discipleship, education and Christian formation may offer a constructively holistic approach that reaches beyond now traditional views of church discipline. ${ }^{1}$

\footnotetext{
1 A version of this paper was presented at the British New Testament Society Conference at King's College London, in September 2012, and is here published in my capacity as a Research Associate in the Field of Mission and Ethics, at the Department of New Testament Studies, Faculty of Theology, University of Pretoria, South Africa.
} 


\section{Introduction}

Intellectual History ${ }^{2}$ is a comparatively recent and dynamic discipline which grew out of the History of Ideas and frequently focuses on how propositions generated in our past are not simply timeless abstractions, located in autonomous and self-sufficient texts, to be studied in isolation from human contexts. ${ }^{3}$ Rather, they are contingent tools, originally wielded with rhetorical purpose, and with a specific audience in mind. Consequently, historic texts are valuably studied within their originating intellectual contexts, with a view to explaining not only their persuasive thrust (the impact sought by those in whose hands such ideas were being honed), but also to reflecting on the expressive contexts out of which the texts arose (the social, political, ethical, or religious - not just the philosophical - contexts impacting on those who forged and then wielded their ideas). ${ }^{4}$ This article will explore both the contingency and variety of sixteenth-century responses to the need for church discipline.

One of the Twentieth Century's significant legacies to New Testament scholarship is the now established awareness that interpretation of biblical texts should not only be historically located (the historical contingency identified above), but is inevitably also circumscribed by the contingency of the interpreter. Exegetes, while seeking to understand texts in their historic, original contexts, are inescapably influenced by their own contemporary contexts and agenda. ${ }^{5}$ An assumption within this article is that those who seek to

2 As with many aspects of the discipline of Intellectual History, even its origins are disputed; cf. D. R. Kelley, The Descent of Ideas: The History of Intellectual History (Aldershot: Ashgate, 2002), who identifies its emergence in the Eighteenth Century, and significant development in concert with eclecticism, as early as the Nineteenth Century.

3 Cf. the lucidly critical description, 'autonomous abstractions which, in their selfpropelled journeyings through time, happened only contingently and temporarily to find anchorage in particular human minds', in S. Collini's 'General Introduction' to S. Collini, R. Whatmore \& B. Young, eds., Economy, Polity and Society: British Intellectual History, 1750-1950 (Cambridge: CUP, 2000): 2.

4 The Cambridge intellectual historian, Quentin Skinner, identifies the goal of such interdisciplinary historical study as being 'able to fit the major texts into their appropriate intellectual contexts, pointing to the fields of meaning out of which they arose, and to which they in turn contributed' (cf. Stefan Collini, 'What is Intellectual History', History Today 35.10 [1985]).

5 Q. Skinner, 'Meaning and Understanding in the History of Ideas', History and Theory 8 (1969): 7, described this in the late 1960s as, 'the extent to which the current historical study of ethical, political, religious, and other such ideas is contaminated by 
understand New Testament attitudes to church discipline, whether in the Sixteenth or Twenty-first Centuries, do so with some measure of contemporary influence. This article will argue that Latin roots of vocabulary associated with church discipline inadvertently impinge on, and skew, subsequent interpretations of New Testament texts. This has had an abiding, even universalising, influence, which now acts as a determining lens, with the unintended consequence of obscuring subsequent access to the New Testament categories.

There are, thus, three interpretative contexts in the frame: the First, Sixteenth, and Twenty-first Centuries. This article seeks to draw attention to the interplay between these contexts, using both social and lexical criteria.

The following statement by a particularly influential intellectual historian will guide my approach to relevant sources from both the Reformation and the First Century - all the while noting that increased understanding of our predecessors does not necessarily require implied criticism of them or their views.

[W]e need to make it one of our principal tasks to situate the texts we study within such intellectual contexts as enable us to make sense of what their authors were doing in writing them. My aspiration is not of course to enter into the thought-processes of long-dead thinkers; it is simply to use the ordinary techniques of historical enquiry to grasp their concepts, to follow their distinctions, to appreciate their beliefs and, so far as possible, to see things their way. ${ }^{6}$

\section{Church Discipline in the Protestant Reformation}

This valuable interplay between historic studies of ideology and social context is, of course, valued by scholars of the Protestant Reformation, who recognise that, "New ideologies not only reflect and justify, but also give rise to, changes in social practice. ${ }^{7}$ We may consider one obvious example. Accounts of history popularly present Luther's nailing of his ninety-five propositions to that recently installed door of

the unconscious application of paradigms whose familiarity to the historian disguises an essential inapplicability to the past'.

6 Q. Skinner, Visions of Politics, vol. 1, Regarding Method (Cambridge: CUP, 2002): 2 .

S. E. Ozment, The Reformation in the Cities: The Appeal of Protestantism to Sixteenth-Century Germany and Switzerland (New Haven: Yale University Press, 1975): 2. 
the Schloßkirche in Wittenberg as an isolated spark, which set in motion the Protestant Reformation. His wider appeal to return ad fontes of Christianity, emphasised by a renewed focus on the importance of the word of God, emerged out of his own wrestling with guilt, or the problem of sin. The formal title of the Ninety-Five Theses draws attention to the practice of indulgences: 'A Disputation on the Power and Efficacy of Indulgences' (Disputatio pro declaratione virtutis indulgentiarum). Its vocabulary and tone present a pointed comment on particular practices espoused by Luther's ecclesiastical contemporaries: the Pope and his bishops, priests, curates, preachers and theologians. The seeds of discontent over the moral state of Christendom and especially some of the abuses perpetrated by the clergy, however, had been germinating decades, even centuries, before Luther's birth. The posting of these theses in 1517 was not, therefore, an abstract and isolated discussion of the place of Christian repentance and the use of indulgences. More obviously it was one of a number of responses to a long-established and widespread social dynamic, and in sympathy with a growing spiritual fervour and piety, necessarily deeply embedded within the church, across much of northern Europe. The roots of this discontent can be located in the late medieval period, and were by no means geographically localised in eastern Germany.

The medieval historian, Robert Swanson, ${ }^{8}$ notes that identifying the origins of the Protestant Reformation remains an unresolved conundrum, but that they surely lie within the evolving state of the increasingly decentralised, and consequently very diverse and fragmented, medieval western church, in which papal control was becoming a declining force. He notes that the tensions and demands experienced at the beginning of the Sixteenth Century 'do seem more shrill and insistent. But such demands were not novel and could be replicated from almost every preceding century. ${ }^{\prime 9}$

A number of disparate, but related, factors can be listed, which gradually inspired a strategic, yet disjointed, movement of reform-a goal which was variously embraced and resisted by elements both of the clergy and laity. First, the Fifteenth and early Sixteenth Centuries

8 Professor of Medieval History at the University of Birmingham, and a specialist in late medieval ecclesiastical history, the economic and social impact of the medieval church, with a particular interest in indulgences and devotion.

9 R. N. Swanson, 'The Pre-Reformation Church' in The Reformation World, ed. A. Pettegree (London: Routledge, 1999): 9-29 (28). 
witnessed significant movements in population, one consequence of which included not only the growth of cities, but also the concomitant shrinking and then amalgamation of many parishes. ${ }^{10}$ This latter encouraged a more direct engagement of the laity in the local governance of the church, leading to their greater influence over the clergy, as well as their heightened expectations regarding the lives and morality of their religious leaders. Swanson writes:

As well as paying the piper, the laity increasingly called the tune, demonstrating a growing awareness of the demands of the Christian religion and appreciation of the ideal state appearance for a priest, together with a real concern to ensure that the clergy they employed met the required standards. This expansion of the laity's role in the church has a significance which cannot be underestimated. ${ }^{11}$

As opposed to a widespread anticlericalism, Swanson argues that complaints about abuses reflected, to a significant degree, not only a desire among laymen that priests become "more rather than less "clerical", but even a growing control over the clergy, expressly to that reforming end. ${ }^{12}$

Thirdly, there was an explosive increase in the number of universities founded between the Eleventh and Fifteenth Centuries, bringing a lasting change to the intellectual landscape of local regions. Theology was the 'queen of the sciences', one of the 'higher faculties' (together with law and medicine), and the goal to which the preparatory trivium and quadrivium pointed. ${ }^{13}$ This multiplication of late medieval universities fostered local differences in both doctrine and theological training, and an increasingly utilitarian focus to learning.

Fourthly, there was the significant impact following from the development and spread of the moveable-type printing press, with its inevitably radical impact on social reform. One particular type of publication, which became far more numerous and accessible, was the genre of devotional text, written in the vernacular. ${ }^{14}$ Each of these four

10 Swanson, 'The Pre-Reformation Church', 15-16.

11 Swanson, 'The Pre-Reformation Church', 16. He goes on to note, 'How far it also reflected a fundamental shift in concepts of authority and control is less easy to determine.'

12 Swanson, 'The Pre-Reformation Church', 23.

13 The trivium included the foundational subjects of grammar, logic and rhetoric, and provides the etymological root of the English word 'trivial'. The quadrivium embraced arithmetic, geometry, music and astronomy.

14 Swanson, 'The Pre-Reformation Church', 21. 
influences contributed markedly to an enhanced, if apparently contradictory, sense both of regionalism and individualism.

Fifthly, and not to be underestimated, there is the impact of a widespread guilt culture. The practice of indulgences, whether purchased with money or earned by devotional or charitable actions, and the celebration of post-mortem masses either played on or responded to this culture..$^{15}$ It must be recognised that Duffy's equally criticised and acclaimed Stripping of the Altars, has to great effect drawn fresh attention to the popularity, adaptability, vibrant piety and liturgically-informed beliefs and practices of 'traditional religion' (not to be understood here with negative connotations) within English Catholicism during the late Middle Ages. ${ }^{16}$ However, it should not be denied that there was nonetheless an embedded guilt culture, potently mixed with a widespread magical superstition. ${ }^{17}$

While two obvious starting-points for exploration of the nature of church discipline in the Sixteenth Century might be on the one hand theological (exegeting a handful of core texts in the Gospels and Pauline epistles, and exploring their treatment by the church fathers) and on the other, ecclesiastical (a growing attempt to redefine what constitutes a 'true' or 'pure' church), my eclectic approach argues that all five of the above factors - the economic, political, pedagogic, commercial, and religious-also impinged significantly on the changing focus of church discipline in the decades of the Protestant Reformation, and served as influencing factors on the subsequent interpretation and application of New Testament texts.

This is not to deny that a widespread dissatisfaction with church practice and a concern to maintain a pure and true church were driving motivations for the Protestant Reformers. ${ }^{18}$ So deep-seated were these convictions that, from the 1556 'Confession of Faith, used in the English Congregation at Geneva', 'discipline' was commonly regarded

15 Swanson, 'The Pre-Reformation Church', 22, 24.

16 Eamon Duffy, The Stripping of the Altars: Traditional Religion in England 14001580 (2nd edn; New Haven: Yale University Press, 2005).

17 Swanson, 'The Pre-Reformation Church', 18-19, notes that church bells might be rung to invoke protection from thunderstorms.

18 U. Lotz-Heumann, 'Imposing Church and Social Discipline' in The Cambridge History of Christianity: Reform and Expansion, 1500-1660, ed. R. Po-Chia Hsia (Cambridge: CUP, 2007): 246, 'social disciplining in a broader sense was implemented to ensure the unity - and ideally homogeneity - of the confessional church on the one hand and its demarcation from rival churches on the other'. 
as one of three defining 'marks of the church'. ${ }^{19}$ Article 29 of the more widely adopted 'Belgic Confession' (1561) identifies these marks thus:

The true church can be recognized if it has the following marks: the church engages in the pure preaching of the gospel; it makes use of the pure administration of the sacraments as Christ instituted them; it practises church discipline for correcting faults [si la discipline ecclésiastique est en usage pour corriger les vices]. In short, it governs itself according to the pure Word of God, rejecting all things contrary to it and holding Jesus Christ as the only Head. By these marks one can be assured of recognizing the true church - and no one ought to be separated from it. ${ }^{20}$

These brief categories in a number of Reformation Confessions, together with their widely shared premise that Scripture be the clear and guiding principle in such matters, have been deeply influential on subsequent churches in the Reformed tradition. Nonetheless, it is clear that not all of the Confessions accorded ecclesiastical discipline the same profile. The Church of England 'Thirty-Nine Articles' (1572) adopted a compromising via media, ${ }^{21}$ and its Article 19, with similar recourse to the 'Word of God', highlights just two identifying marks:

19 These three marks are also identified in the 'First Helvetic Confession', 14/15 (1536); and the 'Scots Confession of Faith Ratification' (1560).

20 Cf. also 'Belgic Confession', Article 32, regarding 'The Order and Discipline of the Church', which states: 'We also believe that although it is useful and good for those who govern the churches to establish and set up a certain order among themselves for maintaining the body of the church, they ought always to guard against deviating from what Christ, our only Master, has ordained for us ... So we accept only what is proper to maintain harmony and unity and to keep all in obedience to God. To that end excommunication, with all it involves, according to the Word of God, is required'; similarly, Article 28 prescribes: 'We believe that since this holy assembly and congregation is the gathering of those who are saved and there is no salvation apart from it, no one ought to withdraw from it, content to be by himself, regardless of his status or condition. But all people are obliged to join and unite with it, keeping the unity of the church by submitting to its instruction and discipline, by bending their necks under the yoke of Jesus Christ, and by serving to build up one another ... And to preserve this unity more effectively, it is the duty of all believers, according to God's word, to separate themselves from those who do not belong to the church, in order to join this assembly wherever God has established it, even if civil authorities and royal decrees forbid and death and physical punishment result. And so, all who withdraw from the church or do not join it act contrary to God's ordinance.'

21 A number of other Confessions focus on just two marks. The 'Geneva Confession' (1536) highlights that the 'holy gospel be purely and faithfully preached, proclaimed, heard, and kept, that his sacraments be properly administered'; and, the 'French Confession of Faith', 27-28 (1559) defines the true church as 'is the company of the faithful who agree to follow his Word, and the pure religion which it teaches; who advance in it all their lives, growing and becoming more confirmed in the fear of God ... there can be no Church where the Word of God is not received, nor profession made of subjection to it, nor use of the sacraments'. 
The visible church of Christ is a congregation of faithful men, in the which the pure Word of God is preached, and the Sacraments be duly ministered according to Christ's ordinance, in all those things that of necessity are requisite to the same.

Elsewhere in the Articles church discipline focuses on inquiring after and justly deposing 'evil Ministers' (Article 26); and detailing how 'wicked persons' should not partake of the Lord's Supper (Article 29), and 'excommunicate persons' should be avoided (Article 33).

Thus, while the Confessions reflect a shared foundation on the word of God and often also on the need for discipline, there was a lack of consensus on how these aspects of faith and practice should be exercised. In the following, it will be clear that the Reformation and subsequent focus on 'discipline' does not presuppose a consistency and uniformity among the Reformers on its place and practice.

\subsection{Middle Ages}

The Reformers' focus on church discipline was not, of course, a reaction to restore a New Testament practice that they perceived had in the meantime gone into abeyance. By the Middle Ages, a complex hierarchy of ecclesiastical courts handled matters of discipline - meting out variously excommunication from the sacraments or excommunication from other benefits of the church, although not excommunication from the church itself. ${ }^{22}$ A second core feature of medieval church discipline, with roots back in the Third Century, was an important connection between communion and public penance. ${ }^{23}$ The practice of penance, whether public or private, became all the more deep-seated and continued as a significant element of both Reformation and, subsequently, Puritan practice. ${ }^{24}$

While on the whole the Reformers enhanced the focus on discipline, ${ }^{25}$ it cannot be seen that they agreed on a uniform and consistently implemented model of it. Indeed, it is not hard to identify at times even a sharp rivalry over the variety of ways in which social

Lotz-Heumann, 'Imposing Church and Social Discipline', 245.

23 A. S. Kidder, Making Confession, Hearing Confession: A History of the Cure of Souls (Collegeville: Liturgical Press, 2010): 139-40.

24 Kidder, Making Confession, Hearing Confession, 139.

25 Lotz-Heumann, 'Imposing Church and Social Discipline', 246. 
and moral control ought to be exercised. ${ }^{26}$ Differences included the boundaries between church and state discipline; the degree to which discipline was handled within an egalitarian or hierarchical framework; and the extent of continuity with medieval practices. The following briefly outlines some of the distinct approaches of the Reformers.

\subsection{Luther}

Unsurprisingly, Luther was a reluctant adopter of a focused implementation of church discipline. His own experience had demonstrated that the word of God itself is a sufficient disciplinarian, and the wider church had, in any case, proved untrustworthy in the task of moral formation. He later conceded that discipline should be limited to exclusion from communion, and this task should be exercised by the local pastor 'through catechizing and preaching'. ${ }^{27}$ In due course, however, Lutheran patterns of church discipline did indeed become much more extensive, and revolved around a highly organised pattern of 'visitations', in which teams from outside the parish would descend on a particular town and interrogate both clergy and laity, who, in turn, were invited to inform on their fellow townspeople. The focus of these interrogatoriae was on both Christian knowledge and morality. ${ }^{28}$

\subsection{Calvin}

Calvin's stance, from the outset, was very different to that of Luther. Significantly, the implementation of church discipline in the city-state church of Geneva required the essential co-operation also of the secular authorities. Implementation of Calvinistic models beyond the unique Genevan context would necessarily, therefore, be different.

For theological reasons, Calvin's stance on the purity of the Lord's Supper necessitated a focus on the purity of those taking part, in a way not dissimilar to the Anabaptists. ${ }^{29}$ The consequence was that church discipline should not only be essential, but also localised in the parish, and specifically around those who would be partaking in communion. ${ }^{30}$

\footnotetext{
26 Lotz-Heumann, 'Imposing Church and Social Discipline', 247, refers to a 'heightened awareness of the necessity of church discipline' and 'an intenstification of church discipline after the Reformation'.

27 Lotz-Heumann, 'Imposing Church and Social Discipline', 251.

28 Lotz-Heumann, 'Imposing Church and Social Discipline', 252-53.

29 Lotz-Heumann, 'Imposing Church and Social Discipline', 259.

30 Lotz-Heumann, 'Imposing Church and Social Discipline', 254.
} 


\subsection{Zwingli}

For Zwingli, the pattern most evident in the New Testament texts, and especially the Acts of the Apostles, was significantly devoid of institutionalisation, there being very little that suggested to him the existence of organised disciplinarian structures in the First Century. To his mind, this presaged an ideally more minimalist approach, focused around local communities of believers. ${ }^{31}$ As with Calvin, the purity of the local congregation around the Lord's Table was the primary goal. Secular authorities should otherwise take responsibility for broader disciplinary matters..$^{32}$

\subsection{Bucer}

Two further Reformers left both a distinct and distinctive mark on the nature and place of church discipline in the Sixteenth Century. They had much in common. Although Continentals, both of them significantly developed their views while staying in England; shared a particularly pastoral focus to their theology; and, had an overriding desire to conciliate and bring unity. ${ }^{33}$

Towards the end of his life, it was said of Bucer, when Regius Professor of Divinity at the University of Cambridge (1550-51), that he,

incessantly clamors that we repent, that we give up the depraved customs of hypocritical religion, that we correct the abuses of feast days, that we more frequently give and hear sermons, that we apply some kind of discipline. He impresses on us many things of this kind ad nauseam. ${ }^{34}$

Indeed, for Martin Bucer, this topic of ecclesiastical discipline 'dominated all others' ${ }^{35}$ In his middle years (1520s), he significantly developed his theology of church discipline, and then went on to

31 M. Gray, The Protestant Reformation: Beliefs and Practices (Brighton: Sussex Academic Press, 2003): 81.

32 Lotz-Heumann, 'Imposing Church and Social Discipline', 259.

33 Bucer was known as 'the apostle of concord', seeking to reconcile Lutherans and Zwinglians (A. Nelson Burnett, The Yoke of Christ: Martin Bucer and Christian Discipline [Kirksville: Northeast Missouri State University, 1994]: 122).

34 Thomas Horton to Francisco Dryander, 15 May 1550, Thesaurus Epistolicus Reformatorum Alsaticorum (TB) XX, p. 180, in the Bibliothèque nationale et universitaire of Strasbourg; cited in, A. Nelson Burnett, 'Church Discipline and Moral Reformation in the Thought of Martin Bucer', Sixteenth Century Journal 22 (1991): 439.

35 M. E. VanderSchaaf, 'Archbishop Parker's Efforts Toward a Bucerian Discipline the Church of England', Sixteenth Century Journal 8 (1977): 85. 
implement and inevitably refine these principles in the following decade in the city of Strasbourg. ${ }^{36}$ Bucer drew a pointed contrast between the penitential focus on discipline, exercised by the church authorities through the Middle Ages, and what he described as the preferable 'yoke of Christ' - although he continued to engage with Catholic systems and find some positive aspects within the late medieval church. ${ }^{37}$ Nelson Burnett writes:

Bucer's rejection of the sacrament of penance had significant ramifications for his system of Christian discipline. In addition to its theological function of transmitting forgiveness, the various elements of the sacrament met other religious and social needs. Bucer had to incorporate into his system of discipline measures which would meet those needs but would be more in accordance with his own evangelical principles. He drew many of those elements from the church's past, as he attempted to purge a system perceived as full of abuses and to restore the penitential and disciplinary system which had existed in the early church. $^{38}$

Bucer particularly evidenced a desire to build a Christian society, focusing on an active service and care for the spiritual well-being of one's neighbour. He urged,

that all the members of Christ recognize and embrace each other most intimately and lovingly, and that they build one another up in the knowledge of and obedience to the son of God most zealously and efficaciously, and that the ministers of the churches know, care for and tend the individual sheep of Christ, as the chief pastor Christ set the example ... In countless places in Scripture, the Lord described and set forth for us this [discipline] which we also have proclaimed so clearly for so many years in life and writings and sermons. ${ }^{39}$

For Bucer, transformation came through Christian discipline, which was not simply punitive, but included religious instruction (especially for children), public and private confession, ${ }^{40}$ and admonition either by pastoral figures or fellow believers. Small, Christian fellowship groups were integral to his system of establishing discipline. In extremis,

36 Burnett, The Yoke of Christ, 55, 'his writings from 1531 to 1534 focused on issues such as the need for regular religious instruction, the value of a precommunion examination, the steps to be taken in disciplining an unrepentant sinner, and the use of excommunication'.

37 Burnett, The Yoke of Christ, 9.

38 Burnett, The Yoke of Christ, 9.

39 Bucer, CO 13:237-38 (26 April 1549).

40 A. Nelson Burnett, 'Church Discipline and Moral Reformation in the Thought of Martin Bucer’, Sixteenth Century Journal 22 (1991): 445. 
public penance or even excommunication might be appropriate, although their purpose was as a deterrent to others and a sign of a sincere commitment to reform ('Besserung'), rather than a means of appeasing God. ${ }^{41}$ Even in these circumstances, instruction remained important - social ostracism should not prevent the unrepentant sinner from hearing the public preaching. ${ }^{42}$

Thus, Bucer did not entirely reject all contemporary Catholic aspects of discipline, but did reject a number of medieval disciplinary practices, and instead looked to the church fathers for guidance.

\subsection{Lasco}

The second continental, who developed his understanding of church discipline within an English context, was significantly influenced by his contemporary Bucer, but is much less well-known. John a $\mathrm{Lasco}^{43}$ (1499-1560) was a Polish migrant Reformer, who, strongly motivated by the pursuit of ecclesiastical unity, played a strategically conciliatory role in bringing together different wings of the Reformation movement. David Wright, the Edinburgh ecclesiastical historian, described him as being of 'an inexorably inclusivist cast of mind' ${ }^{44}$ Lasco wrote an extensive work on church organisation, spanning some 650 folio pages, entitled Forma ac ratio. ${ }^{45}$ The quincentennial of his birth has inspired a flurry of publications engaging with his life, theology and ministry.

Although John a Lasco's influence was, in the long run, limited, his inclusion of disciplina ecclesiastica as a clear distinctive of the true church may have been the most significant of his contributions. ${ }^{46} \mathrm{He}$ certainly distinguished himself from the Lutherans, and even Calvin, in

\footnotetext{
41 Burnett, 'Church Discipline and Moral Reformation', 440-41.

42 I. Hazlett, 'Bucer' in The Cambridge Companion to Reformation Theology, ed. D. Bagchi \& D.C. Steinmetz (Cambridge: CUP, 2004): 110.

43 Jan Łaski; John Laski; Johannes à Lasco.

44 D. F. Wright, Martin Bucer: Reforming Church and Community (Cambridge: Cambridge University Press, 1994): 2.

45 Forma ac ratio tota ecclesiastici ministerii, in peregrinorum, potissimum vero Germanorum Ecclesia ('The Structure and Complete System of the Ecclesiastical Ministry in the Stranger Church, particularly the Dutch Church').

46 M. S. Springer, Restoring Christ's Church: John a Lasco and the forma ac ratio (St Andrews Studies in Reformation History; Aldershot: Ashgate, 2007): 59-60. With regard to the third mark, Springer (Restoring Christ's Church, 60-61), notes that it is unclear whether Lasco is here indebted to Peter Martyr Vermigli, or vice versa. Lasco's Compendium doctrinae (1551) certainly identifies four 'distinguishing characteristics': 'it is brought together by God, observes his divine doctrine, agrees with the teachings of Christ, and follows the apostolic model'.
} 
adopting all three marks of the church - and was followed in so doing by the Scottish church. On many fronts John a Lasco's theology was indebted more to Zwingli and Erasmus - indeed, he inherited much of Erasmus' library.

Forma ac ratio is organised around these marks of the church. His model of church order combined both episcopal and presbyterial patterns; that is, it included a single superintendent as well as a body of elders.

the specific duties of ministers of the Word are to educate the faithful about the 'pure and uncorrupted' doctrine, administer the sacraments, enforce moral discipline within the community, defend the congregation and their practices from critics, and to provide an example of how to live a godly life for all to see. ${ }^{47}$

John a Lasco explored the relationship between theology and the lives of congregants, between theory and practice. Church was a communio corporis Christi. For Lasco, this had implications which significantly emphasised a status of equality among members. ${ }^{48}$ In his particularly congregational model, all members should participate in church discipline, although certain church officers had particular roles to play in this regard. In due course, a far more hierarchical, uniform and punitive model came to dominate the practice of church discipline in Europe, such that Lasco's model was not widely adopted, and then all the more diminished in influence. ${ }^{49}$

Notions of 'love' and 'liberty' combined to shape his view of discipline, which had the aims of being formative, ${ }^{50}$ corrective, restorative and protective. ${ }^{51}$ Key elements included public and private admonitions, excommunication, and the involvement of an adjudicating committee (Kirchenrat). Springer writes:

47 Springer, Restoring Christ's Church, 65. Lasco, C6v, the elders are 'like the senate of the entire church, who maintain the true religion and enforce ecclesiastical discipline'.

48 Notwithstanding himself being born to Polish aristrocratic parents-albeit Poland had an elective monarchy.

49 Springer, Restoring Christ's Church, 95.

50 Springer, Restoring Christ's Church, 97, discipline was 'a tool to maintain doctrinal purity ... and to enforce moral reform'.

51 Springer, Restoring Christ's Church, 97. Restricting access to the communion table was integral to protecting the church. Cf. J. Becker, Gemeindeordnung und Kirchenzucht: Johannes a Lascos Kirchenordnung für London (1555) und die reformierte Konfessionsbildung (Leiden: Brill, 2007), who highlights that church structures have theological justifications. 
The redemptive nature of Lasco's discipline led the public rites for penitence and excommunication to become the principal focus of the refugees' discipline. The Polish reformer writes that if the Kirchenrat finds an offender to be guilty, but the member refuses to acknowledge his error and seek reconciliation, then the matter should be presented to the entire congregation in the form of a public censure. During Sunday worship services, the ministers were to recount to the assembled members the sin that had been committed and the subsequent admonitions that were made ... without revealing the identity of the offender. ${ }^{52}$

\subsection{Conclusion}

This account highlights a number of important points. The word 'discipline' gained a far higher profile in ecclesiastical contexts, and became an important focus of debate as a consequence of social, cultural, political and religious factors. While a number of the Reformation Confessions agreed on the importance of church discipline rooted in the word of God, there were few specifics about its practice. This reflects a diversity among the Reformers of conviction, practice and continuity with the past. The New Testament did not provide them with sufficient basis for universal prescriptions about how discipline should be practised.

\section{Lexical Keys}

In addition to the word 'discipline', 'penitence' also became significant within debates about church practice. The remaining sections of this article discuss: the Latin roots of both these words; the extent to which they have equivalents in New Testament Greek vocabulary; and how their meanings have changed over the centuries.

\section{1 'Discipline', disciplina and $\pi \alpha \_\delta \varepsilon i ́ a$}

The Reformation Confessions, in French and English, settled on 'discipline' as a word that now frames the scope of this subject in ecclesiastical contexts both narrowly and significantly. Contemporary usage of the word is clearly polyvalent, carrying a wide range of noninterchangeable senses, normally transparent from their particular contexts-furthermore, these contexts and meanings are generally not

52 Springer, Restoring Christ's Church, 99. 
confused. Sensitive to the dangers of methodologically naïve word studies, in the following I shall explore this range, and also identify associations with both Latin and Greek.

In military contexts, discipline, as a noun, is a commendable, even a required, quality, describing the person or unit that is well-drilled, ordered, and controlled. There are connotations not only of rigour and professionalism, but perhaps also of pain, hardship and even deprivation. The process of becoming disciplined is an essential and anticipated feature of training, and a matter of pride, rather than something to be avoided. In many military contexts, and most sporting contexts, an individual voluntarily submits to this process of discipline.

In academic contexts, the noun 'discipline' has very different connotations, and refers in a less value-laden way simply to a discrete and recognised branch of advanced learning. There are neither privative nor corrective associations.

In contemporary ecclesiastical contexts, although by no means exclusively so, 'discipline' carries neither of these two connotations. Rather, it involves a measure of censure, is corrective and largely punitive. Rather than being an essential and shared goal, to which all in a community might volunteer, it is rather a sanction applied, normally by those in authority, to an offending individual. It tends to be exercised only in extremis, rather than routinely. In a similar sense, disciplinary hearings are convened in many professional contexts in order to determine whether punishment or sanctions should be applied; and a disciplinarian is one who enforces order and corrects, with elements of admonition and coercion, rather than one who merely instructs or educates.

Each of these three contemporary uses is quite distinct, and their respective contexts for use are discrete. In Classical Latin, however, the sense of corrective punishment is largely absent from the discip- word group. Indeed, there are no inherently privative or punitive connotations to the terms, disciplina, discipulus, $-a$, or disco.

The focus of disciplina embraces teaching, instruction, tuition and training, and, by metonymy, learning, knowledge and science. The context is largely pedagogic, and the notions of correction and punishment are not to the fore. The Latin word discipulus overlaps closely with the English word 'disciple', and, again, carries the dominant context of learning, training and instruction. Lewis \& Short present discipulus as a contraction of disco ('I learn') and puer ('boy'), 
or pupillus ('orphan'), reflecting a one-time association between the child and his education. ${ }^{53}$ Gane's dictionary proposes an alternative construction, in which there is no connection with infant. ${ }^{54}$ Whichever of these reflects a more reliable etymology, any meaningful lexical connection between the disciple and the boy/orphan who engages in learning is at best residual.

By contrast, Hellenistic Greek has a word group with a clearer

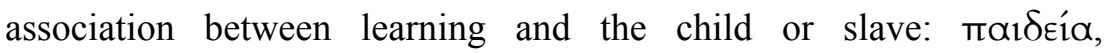

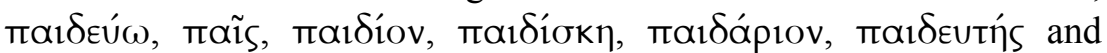
$\pi \alpha 1 \delta \alpha \gamma \omega \gamma$ ós. Significant to our present discussion, $\pi \alpha 1 \delta$ eía is used of the rearing of children in the most general terms, and not merely their education..$^{55}$

Additionally, there are sometimes clearly privative connotations to this word group, which are not present in other Greek verbs in the

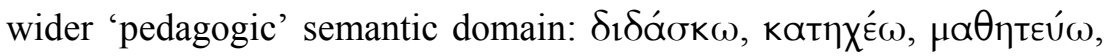

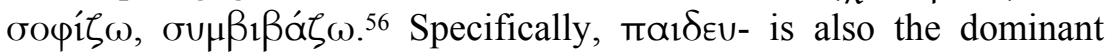
root conveying 'corrective discipline'. ${ }^{57}$ So, while it frequently is used to convey aspects of 'instruction', ${ }^{58}$ 'education', ${ }^{59}$ 'guidance' and

\footnotetext{
53 A Latin Dictionary, ed. C. T. Lewis \& C. Short (Oxford: Clarendon Press, 1879) ad loc.

54 P. G. W. Glare, ed., Oxford Latin Dictionary (2nd edn; Oxford: OUP, 2012) ad loc., dis- + capio + -ulus.
}

55 Cf. Rom. 2:20, 'a corrector ( $\pi \alpha_{1} \delta \varepsilon v t \eta ́$ ) of the foolish, a teacher of children

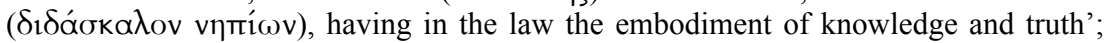
Eph. 6:4, 'And, fathers, do not provoke your children (TÉkva) to anger, but bring them

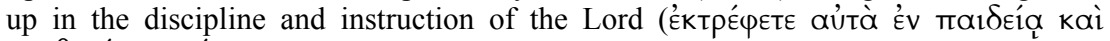

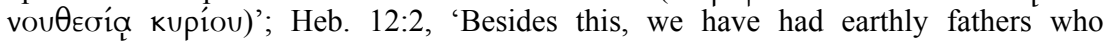

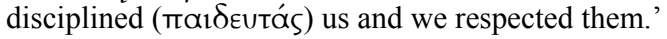

56 For an extensive discussion of teaching terminology in some of the New Testament epistles, see C. S. Smith, Pauline Communities as 'Scholastic Communities': A Study of the Vocabulary of 'Teaching' in 1 Corinthians, 1 and 2 Timothy and Titus (WUNT; Tübingen: Mohr Siebeck, 2012).

57 Cf. 1 Cor. 11:32, 'But when we are judged by the Lord, we are disciplined ( $\pi \alpha 1 \delta \varepsilon v o ́ \mu \varepsilon \theta \alpha$ ) so that we may not be condemned along with the world'; 2 Cor. 6:9, ' $\ldots$ as unknown, and yet well known; as dying, and behold, we live; as punished ( $\pi \alpha 1 \delta \varepsilon v o ́ \mu \varepsilon v o 1)$, and yet not killed'; 1 Tim. 1:20, 'Hymenaeus and Alexander, whom I have handed over to Satan that they may learn ( $\pi \alpha 1 \delta \varepsilon v \theta \tilde{\omega} \sigma 1 v)$ not to blaspheme';

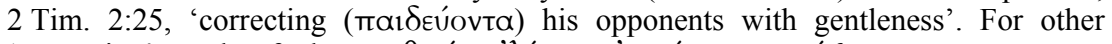

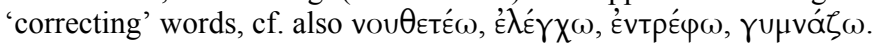

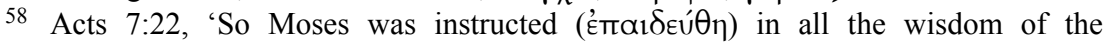
Egyptians and was powerful in his words and deeds.'

59 Cf. Acts 22:3, 'I am a Jew, born in Tarsus in Cilicia, but brought up in this city at the feet of Gamaliel, educated ( $\pi \varepsilon \pi \alpha_{1} \delta \varepsilon \cup \mu \varepsilon$ '́vo $)$ strictly according to our ancestral law.' 
'training', ${ }^{60}$ on occasion it carries connotations of 'rebuke', ${ }^{61}$ 'correction' 62 and 'discipline accompanied by punishment (including whipping or scourging)', ${ }^{63}$ or 'retribution (experienced as suffering)' ${ }^{64}$ Thus, it accommodates a significantly wider range of meanings than that of disciplina in Classical Latin, with the frequent inclusion of clearly negative nuances. It is therefore surprising that it is the Latinderived 'discipline' that now carries the broader range of meanings, and the Greek-derived 'pedagogy' that carries the narrower.

The Oxford English Dictionary offers a diachronic overview of the noun and transitive verb 'discipline'. Early usage lies in the practical instruction or tuition of pupils; that is, discipline concerns the training of those who are disciples, and thus closely follows Latin roots. This training may be moral, in order 'to form the pupil to proper conduct and action'. (As such it is contrasted with doctrina, which is the domain rather of the teacher than the disciple, i.e. the doctor or magister. ${ }^{65}$ The verb is defined as: 'to subject to discipline; in earlier use, to instruct, educate, train; in later use, more especially, to train to habits of order and subordination; to bring under control' ${ }^{66}$ The fifth, sixth and seventh levels of meaning for the noun convey the sense of a method for maintaining order or a system of rules, or the exercise of admonition, censure or power. It is this that is now the dominant connotation of usage in ecclesiastical contexts.

This comparison suggests an interesting similarity between the Hellenistic Greek usage of the $\pi \alpha 1 \delta \varepsilon v$ - word group and some English usage of the noun and verb 'discipline'. In both, the range of connotations is broad-extending from training, instruction and education to order, control and subordination. In the Greek, however, there are also widespread associations with children or minors.

60 Titus 2:11-12, 'For the grace of God has appeared, bringing salvation to all,

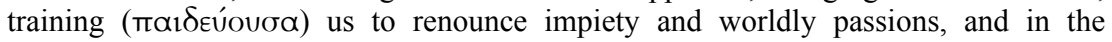
present age to live lives that are self-controlled, upright, and godly.'

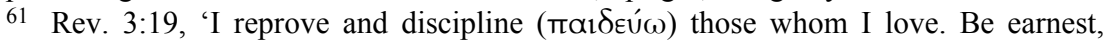
therefore, and repent.'

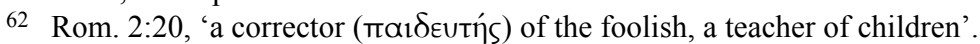

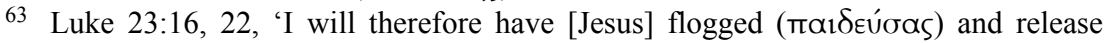
him.'

642 Cor. 6:9, 'as unknown, and yet are well known; as dying, and see - we are alive;

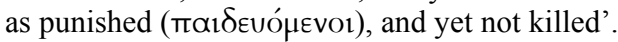

65 Oxford English Dictionary Online (Oxford: Oxford University Press, 2000), ad loc.

66 OED, ad loc. 
It is important to note, however, that although the word 'discipline' became dominant in Reformation debates and attracted some of the punitive connotations of $\pi \alpha_{1} \delta \varepsilon i \alpha$ and $\pi \alpha_{1} \delta \varepsilon v \dot{\omega} \omega$, these particular Greek words occur just nineteen times in the New Testament, and none occurs within passages commonly associated with ecclesiastical discipline. ${ }^{67}$ Indeed, over a third of the occurrences are in a single, short passage (Heb. 12:5-11), which does not itself focus on the ecclesiastical sanction of discipline. Rather, a parallel is drawn between divine discipline (the focus) and parental discipline of a legitimate son by his father.

And you have forgotten the exhortation that addresses you as sons - 'My son, do not regard lightly the discipline ( $\pi \alpha 1 \delta$ sía) of the Lord, or lose heart when you are punished/reproved ( $\varepsilon^{\lambda} \hat{\varepsilon}^{\prime} \gamma \chi \omega$ ) by him; for the Lord

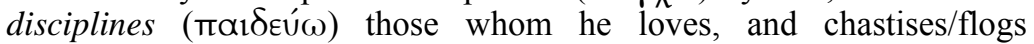

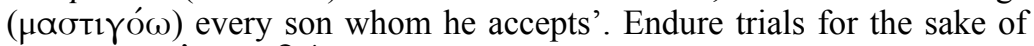
discipline (Eis $\pi \alpha 1 \delta \varepsilon i \alpha v)$. God is treating you as sons; for what son is there whom a father does not discipline ( $\left.\pi \alpha_{1} \delta \varepsilon \varepsilon \dot{\varepsilon 1}\right)$ ? If you do not have

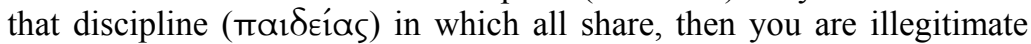
and not sons. Moreover, we had earthly fathers as our instructors

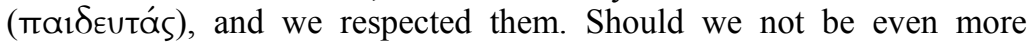
willing to be subject to the Father of spirits and live? For they

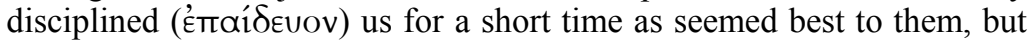
he [did so] for our good, in order that we may share his holiness. Now, discipline $\left(\pi \alpha_{1} \delta \varepsilon i \alpha\right)$ always seems painful rather than pleasant at the time, but later it yields the peaceful fruit of righteousness to those who

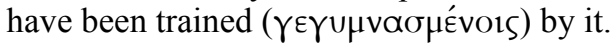

The explicit connection is that education and discipline are the lot of the child (here, viós, rather than the alternative words maĩs or $\pi \alpha 1 \delta$ íov); ${ }^{68}$ and this child is being so educated precisely because he is a son, beloved of his father. The father figure is the principal

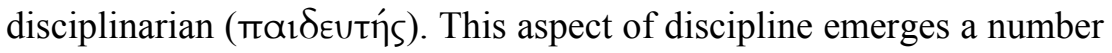
of times in the Bible, both as advice to a parent, and an analogy for God's dealings with his people: 'Know then in your heart that as a man

67 Matt 18:15-20; 1 Cor. 5:1-5; 2 Cor. 2:5-11; 2 Thess. 3:6-15; Eph. 5:6-7, 11; 1 Tim. 5:19-20; Titus 3:10-11; Rom. 16:17; Phil. 3:2. Although not headline 'ecclesiastical discipline' passages, the verb does occur in 2 Tim. 2:24-26 and 1 Tim. 1:19-20 to describe the authoritative action of Timothy as a leader: 'by rejecting faith and a good conscience, some have made shipwreck of their faith, among whom are Hymenaeus and Alexander, whom I have handed over to Satan that they may learn [ivo $\pi \alpha 1 \delta \varepsilon v \theta \tilde{\omega} \sigma i v]$ not to blaspheme'.

68 However, the language reflects that of Proverbs, where maĩs and viós are used apparently interchangeably (Prov. 1:10; 2:1; 3:1, 11, 21; 4:10, 20, etc. and Prov. 4:1). 
disciplines [ $\left.\pi \alpha_{1} \delta \varepsilon \cup \sigma^{\prime} \alpha_{1}\right]$ his son so the LORD your God disciplines [ $\pi \alpha 1 \delta \varepsilon v ́ \sigma \varepsilon 1]$ you' (Deut. 8:5). ${ }^{69}$

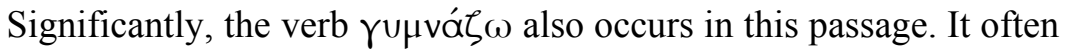
carries some of the more positive athletic imagery that occurs in the English word 'discipline', that is the sense of training, typically achieved by means of a harsh régime - as in the training of a disciplined fighting unit-and, the context is often that of selfdiscipline. ${ }^{70}$ Louw and Nida translate Hebrews 12:11 as 'those who have learned by such punishment ( $\gamma \varepsilon \gamma \cup \mu v \alpha \sigma \mu \varepsilon$ 'vorऽ)' or 'those who because of punishment ( $\gamma \varepsilon \gamma u \mu v a \sigma \mu \varepsilon ́ v o r \varsigma)$ have learned how they must act'. This juxtaposing of learning and punishment, in both the $\pi \alpha 1 \delta \varepsilon v-$ and $\gamma u \mu v a \sigma-$ word groups, sounds strange to contemporary ears where education rarely conveys such obviously punitive connotations.

A similar juxtaposition of educative and reproving language occurs in Revelation 3:19 ('I reprove and discipline [ $\pi \alpha 1 \delta \varepsilon v ́ \omega]$ those whom I love. Be earnest, therefore, and repent'); and 2 Timothy 3:16 ('All scripture is inspired by God and is useful for teaching [ $\pi \rho \mathrm{òs}$

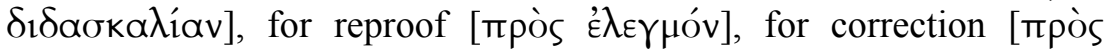

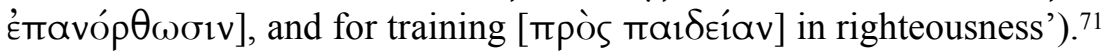
Finally, one notable instance is a phrase Luke repeats in 23:16 and 23:22, in reference to Jesus: 'I will therefore punish him [ $\pi \alpha 1 \delta \varepsilon v ́ \sigma \alpha \varsigma]$ and release him.'

There is, thus, an interesting similarity in that both early English and much early ecclesiastical usage of the word 'discipline' and the Greek words $\pi \alpha_{1} \delta \varepsilon v ́ \omega$ and $\pi \alpha 1 \delta \varepsilon i \alpha$ can at once embrace both the pedagogic and the corrective, with a close alliance between education, discipline, punishment and retribution - often containing elements of hierarchy and even humiliation. By contrast, contemporary English usage distinguishes between the educational and the corrective. Modern educational theory and liberal social attitudes consider them quite

69 Cf. also Deut. 11:2; 21:18; Prov. 3:11-12; 13:24; 15:5; 19:18; 22:15; 23:13; 29:17.

70 Cf. also 1 Tim. 4:7, 'Have nothing to do with irreverent, silly myths. Rather train ( $\gamma$ ú $\mu$ va $\varepsilon$ ) yourself for godliness'; Heb. 5:14, 'solid food is for the mature, for those who have their powers of discernment trained ( $\gamma \varepsilon \gamma \cup \mu v \alpha \sigma \mu \varepsilon$ v́ $\alpha$ ) by constant practice to distinguish good from evil'; 2 Pet. 2:14, 'They have eyes full of adultery, insatiable for sin. They entice unsteady souls. They have hearts trained ( $\gamma \varepsilon \gamma u \mu v \alpha \sigma \mu \varepsilon ́ v \eta v)$ in greed. Accursed children!'; 1 Tim. 4:8, 'while bodily training ( $\gamma$ vuvaoía) is of some value, godliness is of value in every way'.

71 See discussion of this verse in Smith, Pauline Communities as 'Scholastic Communities', passim. 
distinct categories and processes. Consequently, today's readers of the New Testament are likely to respond to texts that are associated with ecclesiastical discipline in ways different to both the original and medieval or early modern readers.

It is also significant that while 'discipline' became a dominant word in church corrective contexts, $\pi \alpha 1 \delta \varepsilon v ́ \omega$ and $\pi \alpha 1 \delta \varepsilon i ́ \alpha$ do not share a similarly high profile in New Testament ecclesiastical corrective contexts. This may similarly create for today's readers some misleading correspondences.

\section{2 'Penitence'}

The complex nexus between English, Latin and Greek in another group of words widely assumed to be adequate translations of each other is also instructive in exploring ecclesiastical discipline - again by virtue of the extent to which the domains in the respective languages do not completely overlap.

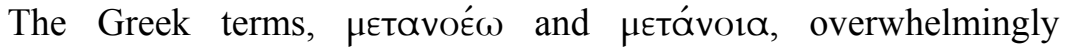
translated in biblical sources by 'repent/repentance', should be regarded as having rather less moral intensity than is found in English. E. F. Thompson, in a well-illustrated, early twentieth-century publication, extensively explores Classical Greek usage of $\mu є \tau \alpha$ vó́ $\omega$, and concludes that, in this early period, it is a purely intellectual term, reflecting a reconsideration or change of opinion - not very distant, that is, from its etymology. ${ }^{72}$ By contrast, the verb $\mu \varepsilon \tau \alpha \mu \varepsilon \dot{\varepsilon} \lambda$ o $\alpha_{1}$, much less common in the New Testament, more frequently carries a sense of regret, and pertains more to feeling than intellect. ${ }^{73}$ Interestingly, however, it is not normally translated as 'repent'. ${ }^{74}$ However, Thompson further identifies that in the period between Aristotle and the end of the First Century CE, this classical, intellectual meaning of $\mu \varepsilon t \alpha$ vó́ $\omega$ broadened to embrace variously regret or a change of

72 E. F. Thompson, METANOES and METAMEAEI in Greek Literature until 100 $A D$, Including Discussion of Their Cognates and of Their Hebrew Equivalents (Chicago: University of Chicago Press, 1908): 10.

73 Thompson, METANOES and METAMEAEI in Greek Literature, 11. Cf. this clear sense of regret in $\mu \varepsilon \tau \alpha \mu \varepsilon \dot{\varepsilon}{ }_{\text {o }} \alpha_{1}$, combined both with specific reference to grief and the term $\mu \varepsilon t a ́ v o 1 \alpha$, in 2 Cor. 7:8-9; and, from the context, the probable implication of regret also in Matt 27:3.

74 Cf. R. N. Wilkin, 'New Testament Repentance: Lexical Considerations', Journal of the Grace Evangelical Society 2 (1989). 


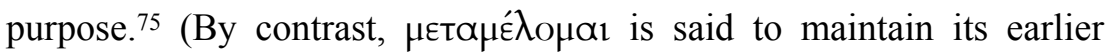
connotation of regret.) $)^{76}$ Nonetheless, in regard to New Testament usage, Thompson argues that $\mu \in t \alpha$ voé $\omega$ reflects a change of purpose, indeed a change of life, from evil to good, but 'it is never identified with sorrow'. ${ }^{77}$ Thus, in the New Testament, both the verb and the noun are never used merely of intellectual action, but, are also never used of emotional action. ${ }^{78}$

By contrast, the English word 'repent' now has an integral sense of regret, remorse, and the apparent intention to reform. The rather weakened sense of simply changing one's mind, incorporated within

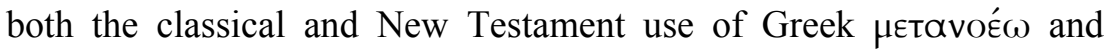
нєTóvoia, is now regarded as quite archaic and long obsolete.

In explanation of this change, English usage reflects greater dependence at this point on Latin roots, following the Vulgate's adoption of paenitentia for $\mu \varepsilon \tau$ óvora. It is significant here for the present discussion that Latin, the dominant ecclesiastical language for so many centuries in the west, has played a distinct role in framing contemporary, English categories. The feminine noun paenitentia and the associated verb paeniteo are described by Lewis \& Short as being significantly and lastingly influenced by the root poena (with its strong affinity with criminal law, and association with the Greek, moiví)..$^{79}$ In Latin, the senses of paenitentia and paeniteo range across indemnification, compensation, satisfaction, expiation, punishment, and penalty. P. G. W. Glare highlights 'regret' as the dominant sense of both Latin terms. ${ }^{80}$ Walden, in an 1896 essay, defending himself against a footnote in a publication by B. F. Westcott (in which the latter

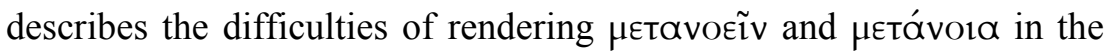
Revised Version translation, stating, 'it was impossible to displace repent, repentance'), ${ }^{81}$ uses the colourful language:

\footnotetext{
75 Thompson, METANOES and METAMEAEI in Greek Literature, 14.

76 Thompson, METANOES and METAMEAEI in Greek Literature, 16.

77 Thompson, METANOES and METAMEAEI in Greek Literature, 24.

78 Thompson, METANOES and METAMEAEI in Greek Literature, 28.

79 Lewis \& Short, A Latin Dictionary, ad loc. The verb commonly occurs in an impersonal form, e.g. paenitet me. Note the spelling variations between the verb punio, 'I punish', and the rare form, poenio.

80 Glare, Oxford Latin Dictionary, ad loc.

81 B. F. Westcott, Some Lessons of the Revised Version of the New Testament (London: Hodder, 1897): 106, fn. 1.
} 
Repentance is a word of classical Latin origin and of Latin theological and ecclesiastical descent. The core of it is not mind, but pain. The note of it is not of emancipation, but of condemnation. The scope of it is not spiritual, but juridical. The working of it is not joyful, but sorrowful. ${ }^{82}$

Fully aware that words have a tendency to outgrow or abandon their earlier meanings, Walden nonetheless argues that paenitentia 'has been endowed with an extraordinary determination to hold on to its original meaning', ${ }^{83}$ It was $\mu \varepsilon \tau$ óvoro which later aggregated to itself the sense of pain associated with paenitentia (and $\mu \varepsilon \tau \alpha \mu \varepsilon \dot{\lambda} \mathrm{o} \mu \alpha 1) .{ }^{84}$

In Greek, the connotations of molví are narrower, but similarly negative, referring to blood-money, or other satisfaction or requital by means of a penalty. In both Latin and Greek, Poena herself was the goddess of punishment or vengeance. Returning to paeniteo, the recognition of having caused displeasure, and therefore grieving, rueing, regretting an action is dominant. Similar associations exist, of course, with the English 'repent'. By extension, the Oxford English Dictionary argues that the adjective 'sorry' was associated with 'sorrow' and its connotations of distress and suffering: 'As a result, sorrow $\mathrm{n}$. has exerted semantic and possibly formal influence on the ... word [sorry]'. ${ }^{85}$

This nexus between penitence and repentance, which emerges through Latin influence, may result in a misleading correspondence in translations of the common New Testament words $\mu \in t \alpha$ vó́ $\omega$ and нєтóvola. ${ }^{86}$

82 T. Walden, The Great Meaning of Metanoia: An Undeveloped Chapter in the Life and Teaching of Christ (New York: Thomas Whittaker, 1896): 105.

83 Walden, The Great Meaning of Metanoia, 109. He identifies a Sanskrit root, Pû, 'to cleanse from dirt', and argues for an abiding sense of purgation (p. 111).

84 Walden, The Great Meaning of Metanoia, 114. He further points out that it was Tertullian's De Poenitentia which made an early and significant connection between 'repentance' and regret: 'Repentance, men understand, so far as nature is able, to be an emotion of the mind arising from disgust' (Tertullian, De Poenitentia, 1). Further blame is attributed, vociferously, to the Roman church for strengthening this connection; but greater surprise is expressed by Walden that the Reformation only served to make this transition permanent (p. 121-22).

85 Oxford English Dictionary Online, ad loc.

86 A widespread connection between 'discipline' and 'penitence', exemplified in the title of the following: N. Marshall, The Penitential Discipline of the Primitive Church for the First 400 Years after Christ: Together with Its Declension from the Fifth Century downwards to the Present State - Impartially Represented (Oxford: John Henry Parker, 1844). 


\section{Conclusion}

The social and religious context of the Reformation resulted in church discipline necessarily acquiring a profile and emphasis that are not reflected in the New Testament.

The resulting prominence of 'discipline' as a key term then raises a number of questions about continuity and change within and across languages. The Latin term disciplina was rather more positive than the wider range of connotations attributed to the Greek terms $\pi \alpha 1 \delta \varepsilon i \alpha$ and $\pi \alpha 1 \delta \varepsilon \cup ́ \omega$; but, its transition into contemporary English has lost this distinctive. By contrast, the Latin terms paeniteo/r and paenitentia have rather more negative connotations than New Testament usage of

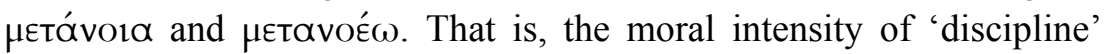
more closely follows the Greek, than the Latin; whereas the moral intensity of 'repent' more closely follows the Latin, than the Greek.

Both the prominence of 'discipline' as an ecclesiastical term and practice following the Reformation and the changes in meaning between New Testament Greek and contemporary English (via Latin) have resulted in making it difficult for contemporary interpreters to access New Testament emphases about 'church discipline'.

A re-envisioning of church discipline within a broader frame of Christian formation (discipleship) may prove to be a much more helpful category, both for theoreticians and practitioners. This will permit embracing into the debate the wider categories of education and learning that are extensively used especially in the Pauline correspondence. 